\title{
Pengembangan Human Machine Interface (HMI) pada Simulator Sortir Bola sebagai Media Pembelajaran Otomasi Industri
}

\author{
Helmy Rahadian ${ }^{1 *}$ dan M Ary Heryanto ${ }^{2}$ \\ ${ }^{1,2}$ Program Studi Teknik Elektro, Fakultas Teknik, Universitas Dian Nuswantoro, Semarang, \\ Jawa Tengah Indonesia \\ *helmyrahadian@dsn.dinus.ac.id
}

\begin{abstract}
Abstrak - Human Machine Interface (HMI) dan Programmable Logic Controller (PLC) digunakan luas di industri guna memonitor dan mengatur proses produksi. Sebagai bagian dari teknologi otomasi industri, penguasaan keahlian dan keterampilan mendesain HMI dan memprogram PLC menjadi kebutuhan mutlak terlebih di era industri 4.0 yang menuntut tenaga kerja profesional dan kompeten. Guna memenuhi tuntutan tersebut, Program Studi Teknik Elektro Universitas Dian Nuswantoro telah melakukan evaluasi terhadap kurikulum khususnya pada mata kuliah Elektronika Industri. Berdasarkan masukan dari stakeholder, Program Studi menambahkan capaian pembelajaran mata kuliah yang mendukung profil lulusan dengan penguasaan teknologi otomasi industri khususnya PLC dan HMI. Selain itu, sebuah simulator sortir bola telah rutin digunakan sebagai media pembelajaran otomasi industri. Namun, simulator tersebut terbatas untuk media pembelajaran PLC. Oleh karena itu, perlu dilakukan pengembangan sistem HMI pada simulator. Makalah ini membahas perancangan dan pengembangan sistem HMI berbasis panel Mitsubishi GOT2000 menggunakan aplikasi GT Designer3. Pengembangan sistem HMI dimulai dari penentuan I/O dan parameter proses sortir, pembuatan layout, modifikasi ladder diagram dan pengujian. Berdasarkan hasil pengujian yang telah dilakukan, sistem HMI dapat bekerja dengan baik sehingga secara teknis simulator sortir bola telah mendukung proses pembelajaran teknologi otomasi industri baik PLC maupun HMI.
\end{abstract}

Kata Kunci : otomasi, pembelajaran, simulator, PLC, HMI

\begin{abstract}
Human Machine Interface (HMI) and Programmable Logic Controller (PLC) are widely used in the industry to monitor and control the production process. As part of industrial automation technology, expertise in designing HMI and programming PLC are an absolute necessity especially in the industrial 4.0 era which demands a professional and competent workforce. To meet these requirements, Program Studi Teknik Elektro Universitas Dian Nuswantoro has evaluated the curriculum, especially in the Elektronika Industri course. Based on stakeholder recommendation, learning outcomes are modified to support the graduate's profile that has expertise in industrial automation technology. Furthermore, a ball sorting simulator has been used as a medium for learning industrial automation. Unfortunately, the simulator only supports PLC learning. Therefore, it is necessary to develop the HMI system in the simulator. This paper explains the design and development of the HMI system based on Mitsubishi GOT2000 using the GT Designer 3 application. The development of the HMI system starts from determining $I / O$ and process parameters, making the layout, modifying the ladder diagram, and testing. Based on the test results, the HMI system can work well so that technically the ball sorting simulator has supported the learning of industrial automation technology both in PLC and HMI fields.
\end{abstract}

Keywords : automation, learning, simulator, PLC, HMI

\section{Pendahuluan}

Programmable Logic Controller (PLC) dan Human Machine Interface (HMI) menjadi bagian penting dalam sistem otomasi industri. PLC merupakan piranti yang dapat diprogram untuk melakukan fungsi pengendalian pada sistem yang sederhana maupun kompleks. Terkadang PLC digunakan bersamaan dengan piranti pengendali lain seperti PID, PAL dan fuzzy controller [1].

Di sisi lain, HMI berperan dalam membangun interaksi yang user friendly antara manusia sebagai operator dengan mesin. HMI digunakan untuk memonitor dan memahami jalannya suatu proses. HMI memiliki kapabilitas untuk memberikan notifikasi berupa alarm audio maupun visual apabila dalam proses produksi terjadi situasi yang 
tidak normal. Pada aplikasi tertentu seperti automotive, HMI juga berperan penting dalam memastikan keselamatan baik pada pengendara maupun kendaraannya [2].

Sejalan dengan perkembangan teknologi otomasi, teknologi HMI juga mengalami peningkatan. HMI yang pada mulanya hanya berupa tombol dan lampu kini mampu memonitor dan menganalisis data kompleks dari proses yang begitu rumit [3]. HMI berevolusi dari generasi ke generasi. Perkembangan komputer dan teknologi digital pada Industri 3.0 melahirkan HMI generasi pertama (HMI 1.0), selanjutnya dengan perkembangan industrial network membawa HMI pada generasi kedua. HMI 3.0 lahir didukung oleh ethernet dan jaringan internet. Saat ini, diperkirakan dengan mulai maraknya teknologi AR dan VR akan melahirkan HMI 4.0 [4].

Berdasarkan survei yang dilakukan oleh [5], banyak perusahaan telah mengenal konsep industri 4.0 namun belum mengetahui cara mengimplementasikannya. Perusahaan akan banyak berinvestasi untuk pelatihan bagi karyawannya karena akan semakin banyak penggunaan mesin otomatis dan modern [6]. Di Indonesia sendiri, dengan jumlah angkatan tenaga kerja terbesar ke-4 di dunia namun ternyata masih banyak yang tidak memiliki kompetensi memadai [7]. Peran dunia akademik menjadi sangat penting dalam menyiapkan tenaga kerja yang kompeten bahkan kini dikenal konsep Education 4.0 guna mewujudkan hal tersebut [8].

Saat ini, trainer PLC dan HMI sendiri mulai banyak digunakan sebagai media pembelajaran teknologi otomasi di kalangan akademik. Beberapa trainer menggunakan produk dari produsen produk otomasi seperti Siemens [9], Schneider [10] dan Omron [11]. Trainer lain dirancang dan dibangun mandiri menggunakan Arduino [12] dan Raspberry Pi dengan GUI HMI yang dikembangkan dengan bahasa pemrograman Python [13].

Program Studi Teknik Elektro Universitas Dian Nuswantoro sendiri telah melakukan upaya-upaya menghadapi tantangan era industri 4.0. Evaluasi dilakukan terhadap kurikulum khususnya pada mata kuliah Elektronika Industri. Capaian pembelajaran disesuaikan dengan masukan dari stakeholder untuk mendukung profil lulusan yang berkompeten dalam bidang otomasi industri khususnya PLC dan HMI.

Program Studi juga telah menyediakan simulator sortir bola sebagai media pembelajaran otomasi industri. Namun pada saat ini simulator tersebut belum memiliki sistem HMI yang memadai sehingga masih terbatas untuk pembelajaran PLC saja. Berdasarkan hal tersebut maka perlu dibuat sistem HMI pada simulator. Pengembangan sistem HMI dilakukan menggunakan panel HMI GOT2000 dan aplikasi GT Designer3 dari Mitsubishi. Diharapkan dengan pengembangan sistem HMI ini dapat mendukung target capaian pembelajaran dan profil lulusan yang kompeten di bidang otomasi industri khususnya PLC dan HMI.

\section{Simulator Sortir Bola}

Simulator sortir bola (Gambar 1) yang dimiliki Program Studi mengadopsi application examples yang dipublikasikan oleh OMRON [14]. Simulator digunakan mahasiswa untuk memahami proses pengemasan sejumlah tertentu bola tenis meja ke dalam boks. Instrumen yang terdapat pada simulator adalah:

- Sebuah PLC Mitsubishi tipe FX5U.

- Dua buah motor DC sebagai penggerak konveyor bola dan konveyor boks,

- Dua buah sensor photoelectric guna mendeteksi bola dan boks.

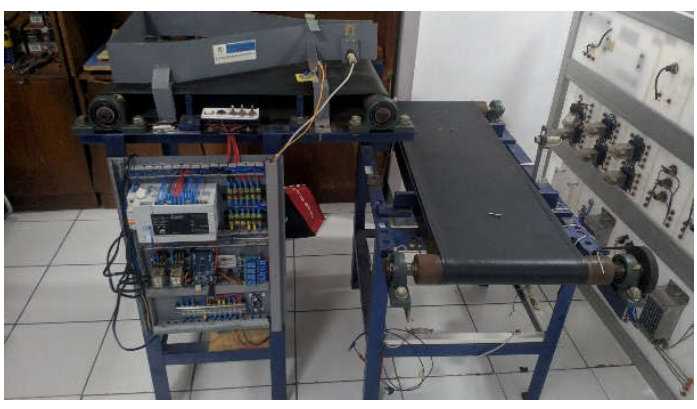

Gambar 1. Simulator sortir bola

Sebuah panel disediakan untuk mengoperasikan simulator. Panel ini (Gambar 2) terdiri dari beberapa tombol (push button) dan saklar (toggle switch) mekanis. Melalui panel ini, user berinteraksi dengan simulator. User memilih mode operasi yang diinginkan (manual/auto) serta memulai dan menghentikan operasi simulator dengan menekan tombol atau saklar tertentu pada panel ini. Tombol dan saklar pada panel terhubung melalui serangkaian kabel menjadi masukan bagi PLC.

Masalah yang sering terjadi pada simulator adalah keausan pada tombol dan saklar serta tidak rekatnya sambungan solder antara terminal 
komponen dengan kabel mengakibatkan sinyal ke PLC menjadi tidak stabil (tidak responsif). Banyaknya kabel yang digunakan juga menyulitkan apabila harus dilakukan penggantian.

Simulator juga memiliki keterbatasan karena proses yang berjalan pada simulator sepenuhnya dikendalikan oleh PLC. Setiap ada perubahan parameter seperti setpoint jumlah bola yang harus disortir, maka parameter tersebut harus diperbarui melalui modifikasi program PLC. Setelah itu, program PLC diunggah ulang dari PC ke PLC.

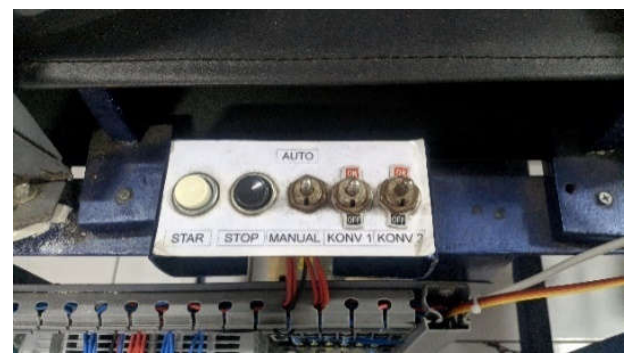

Gambar 2. Panel untuk mengoperasikan simulator sortir bola

\section{Human Machine Interface (HMI)}

Masalah dan keterbatasan yang muncul pada interaksi konvensional (tombol dan saklar) bisa diminimalkan menggunakan sistem HMI modern. Dalam pengembangan ini, sistem HMI modern diwujudkan dengan menambahkan panel monitor (display unit) touchscreen Mitsubishi GOT2000 yang diprogram menggunakan aplikasi GT Designer3. Panel monitor ini akan menggantikan panel konvensional tombol dan saklar.

Penambahan sistem HMI modern pada simulator bola mensyaratkan pemahaman terhadap proses yang akan dijalankan. Hal ini disebabkan karena setiap sistem HMI merupakan implementasi yang disesuaikan dengan proses. Tidak ada standar pada sistem HMI yang bisa mewakili setiap proses [15]. Namun demikian, dalam mendesain HMI tetap harus memperhatikan universalitas dan mengedepankan interaksi yang intuitif [16].

Proses sortir bola dimulai dengan pemilihan mode proses manual atau auto oleh operator. Pada mode manual, kendali proses sepenuhnya ada di tangan operator. Jalannya konveyor bola, konveyor boks serta jumlah bola yang akan dimasukkan ke dalam boks diatur dan dikendalikan secara manual oleh operator. Pada mode auto, proses pada simulator mengikuti sepenuhnya pada program ladder di PLC.
Berdasarkan proses yang berjalan pada simulator, pengembangan sistem HMI berlangsung melalui tahapan yaitu:

\subsection{Menentukan piranti I/O}

Piranti I/O yang dimaksud adalah piranti yang menjadi sarana antarmuka antara user dan simulator yakni tombol dan saklar pada panel pengendali. Tombol dan saklar mekanis akan diubah menjadi obyek visual (grafis) pada panel monitor HMI.

Pada simulator sortir bola, semua piranti yang divisualisasikan merupakan piranti input, yaitu:

- Push button START

- Push button STOP

- Toggle switch mode manual/auto

- Toggle switch mode manual konveyor 1 (konveyor untuk memindahkan bola)

- Toggle switch mode manual konveyor 2 (konveyor untuk memindahkan boks)

\subsection{Menentukan parameter proses}

Parameter proses atau disebut juga dengan process variable merupakan nilai maupun informasi yang diukur atau dikendalikan selama proses berlangsung. Parameter proses pada simulator sortir bola adalah:

- Jumlah bola yang akan disortir

- Jumlah bola yang sudah masuk ke boks

- Informasi tahapan proses

\subsection{Menentukan alamat perangkat I/O dan parameter proses}

User bertugas untuk mengendalikan proses sortir bola, memasukkan nilai setpoint bola yang harus disortir dan berbagai tindakan lain. Semua hal itu dilakukan melalui panel monitor HMI yang tersusun atas berbagai obyek HMI. Perintah dan data yang dimasukkan oleh user dikirimkan dari panel HMI ke PLC. Sebaliknya, PLC akan menyediakan nomor tahapan proses yang sedang berlangsung untuk ditampilkan pada panel monitor HMI.

Sinyal perintah, data maupun informasi tersebut dikomunikasikan antara obyek HMI dan device PLC melalui alamat yang telah ditentukan. Device sendiri merupakan alamat internal memori yang memiliki berbagai tipe. 
Tabel 1 menunjukkan korelasi antara obyek HMI dengan device PLC.

Tabel 1. Korelasi obyek HMI dan device PLC

\begin{tabular}{|l|l|l|}
\hline Nama obyek HMI & $\begin{array}{l}\text { Tipe obyek } \\
\text { HMI }\end{array}$ & Device PLC \\
\hline START & Tombol & M20 \\
STOP & $\begin{array}{l}\text { Tombol } \\
\text { MAN/AUTO (Mode) }\end{array}$ & Tombol \\
RUN KVY 1 (Mode & Tombol & M23 \\
Manual) & & \\
RUN KVY 2 (Mode & Tombol & M24 \\
Manual) & & \\
Jumlah Bola (Set Point) & Numerik & D2 \\
Jumlah Bola (Masuk) & Numerik & CN0 \\
Step No. (Integer) & Numerik & D0 \\
Step Info (Teks) & Alphanumerik & D0 \\
\hline
\end{tabular}

\subsection{Perancangan layout HMI}

Layout HMI merupakan tata letak obyek-obyek HMI yang disusun menurut ketentuan tertentu. Layout proses sortir bola yang cukup sederhana bisa ditampilkan dalam satu layar HMI saja. Berdasarkan panduan desain layout HMI oleh [17] dan [18], abu-abu (grey) dipilih sebagai warna latar belakang (background) layout HMI.

Layout HMI simulator sortir bola terbagi menjadi tiga (3) bagian, yaitu:

\section{A. Header}

Bagian header berisi penjelasan atau memberikan informasi umum mengenai production atau process plant. Bagian ini dibuat menggunakan obyek HMI berupa teks dan obyek gambar lambang Universitas Dian Nuswantoro.

\section{B. Parameter proses}

Bagian ini menampilkan parameter-parameter yang dimonitor atau dikendalikan selama proses sortir bola.

- Parameter pertama: setpoint jumlah bola yang diinginkan untuk dikemas dalam boks, dibuat menggunakan obyek numerical input.

- Parameter kedua: informasi jumlah bola yang telah masuk ke dalam boks. Dibuat dengan obyek numerical display.

- Parameter ketiga: step number dan step info. Parameter step number dibuat dengan obyek numerical display yang menampilkan angka/numerik saja sedangkan untuk step info dibuat menggunakan obyek comment display yang memiliki kemampuan menampilkan angka dan huruf (alphanumeric).

\section{Panel kendali}

Bagian ini terdiri atas beberapa obyek HMI berupa tombol untuk mengendalikan proses sortir bola, yaitu:

- Tombol START dan STOP merupakan obyek push button bertipe momentary, memberikan sinyal ON (high level) hanya ketika tombol ditekan (disentuh).

- Tombol pemilih mode operasi (MAN/AUTO) merupakan obyek push button dengan tipe alternate.

- Tombol RUN KVY 1 dan RUN KVY 2, untuk menjalankan konveyor 1 dan konveyor 2 secara manual. Tombol ini bersifat alternate.

Pada tombol bertipe alternate, setiap kali tombol ditekan akan menghasilkan nilai sinyal yang berlawanan. Misal saat pertama kali ditekan menghasilkan sinyal ON maka pada penekanan tombol kedua kali menghasilkan sinyal OFF.

\section{Programmable Logic Controller (PLC)}

PLC merupakan pengendali utama proses sortir bola. Program PLC atau ladder diagram dibuat untuk menjalankan proses sortir bola sesuai dengan mode operasi yang dipilih oleh operator.

Aliran atau flow chart program PLC mode otomatis ditunjukkan oleh Gambar 3 yang terdiri atas empat tahapan utama, yaitu:

- Standby (Step 10)

- Menjalankan konveyor 2 (Step 20)

- Menjalankan konveyor 1 (Step 30)

- Menjalankan konveyor boks (Step 40) 


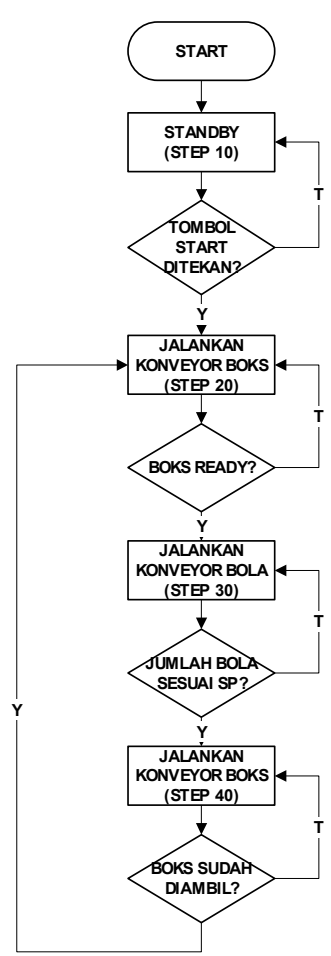

Gambar 3. Flow chart program PLC

Dengan adanya penambahan sistem HMI maka perlu dibuat sebuah rutin program untuk membaca nilai parameter proses yang diakibatkan oleh penekanan tombol pada panel monitor HMI oleh user. Ladder diagram PLC dikembangkan menggunakan aplikasi GX Works 3. Ladder diagram tersusun atas device-device yang merepresentasikan rangkaian elektrik. Setiap device dibuat dengan memberikan alamat yang unik [19]. Alamat device yang digunakan bersama antara PLC dan HMI telah dijelaskan pada

Tabel 1 sedangkan tipe device dijelaskan sebagai berikut:

- Internal relay: tipe ini digunakan untuk device yang bersifat diskrit seperti tombol. Notasi internal relay adalah M. Merupakan tipe device pada obyek tombol yang ada di panel kendali.

- Data register: menyimpan nilai numerik (integer). Merupakan tipe device pada obyek parameter proses.
- Counter: menampung nilai cacahan (counter). Khusus digunakan pada parameter proses yang menunjukkan jumlah bola masuk ke boks.

\section{Hasil dan Pembahasan}

Pada bagian ini akan dijelaskan hasil perancangan dan pengembangan sistem HMI serta pengujiannya.

\subsection{Layout HMI}

Hasil desain layout HMI yang telah dibuat dan di-install pada panel monitor GOT2000 berukuran 7 inci dengan resolusi 640x480 pixel ditunjukkan oleh Gambar 4.

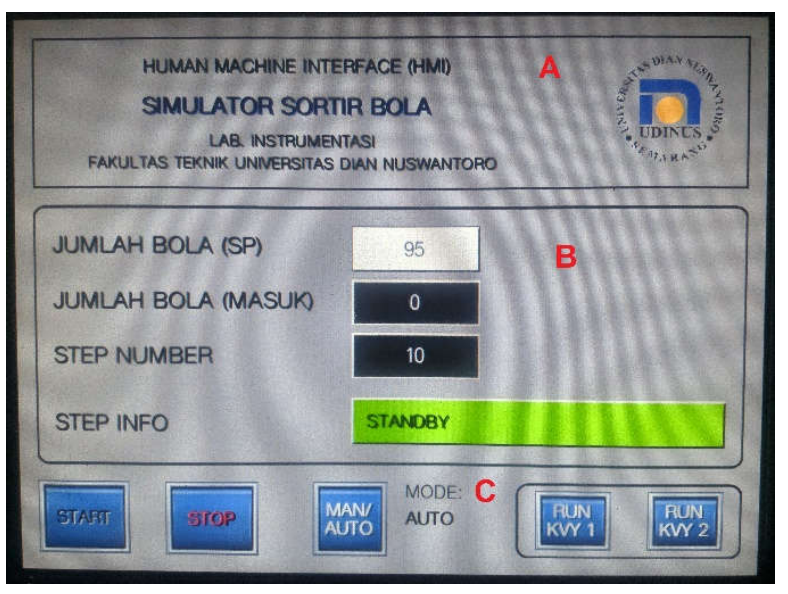

Gambar 4. Hasil desain layout HMI

\section{A. Header}

Bagian header berisi informasi umum tentang simulator sortir bola. Bagian ini murni berupa obyek yang dibuat di sisi HMI dan tidak memiliki device apapun yang terhubung ke PLC. Teks dan gambar pada header bersifat read only.

\section{B. Parameter proses}

Tersusun atas beberapa obyek HMI untuk menampilkan dan memasukkan parameter proses:

- Parameter setpoint/Jumlah Bola (SP): berupa masukan numerik yang bisa di-update nilainya dengan angka integer (bersifat write-able) oleh user. Nilai parameter ini menjadi acuan bagi simulator pada saat proses memasukkan bola ke dalam boks (Step 30).

- Parameter Jumlah Bola (Masuk): berupa obyek HMI yang bersifat read-only. Berfungsi menampilkan jumlah bola yang telah masuk (atau yang telah disortir) ke dalam boks. Nilai 
parameter berubah tiap kali sensor photoelectric di ujung konveyor 1 mendeteksi bola (terjadi pada Step 30).

- Parameter Step No.: bersifat read-only. Menampilkan nomor tahapan proses sortir bola yang sedang berlangsung. Nilainya berubah tiap kali berpindah dari satu tahap ke tahap proses berikutnya. Informasi yang ditampilkan berupa angka (integer).

- Parameter Step Info: bersifat read-only. Menampilkan penjelasan (deskripsi) mengenai tahapan proses sortir yang sedang berlangsung. Informasi yang ditampilkan berupa teks.

\section{Panel kendali}

Tersusun atas obyek HMI berupa tomboltombol (push button) digunakan untuk mengatur operasional simulator, yaitu:

- Tombol START dan STOP: digunakan untuk memulai dan menghentikan simulasi. Tombol ini hanya bisa digunakan pada mode otomatis.

- Tombol MAN/AUTO: digunakan untuk memilih mode operasi simulator, otomatis ataukah manual. Informasi mode operasi ditampilkan pada teks disebelah kanan tombol.

- Tombol RUN KVY 1 dan RUN KVY 2: digunakan untuk menjalankan konveyor bola dan boks secara manual. Tombol hanya aktif pada mode operasi manual.

\subsection{Program PLC}

Ladder diagram PLC telah dimodifikasi guna menyesuaikan dengan penambahan sistem HMI. Sebuah rutin program telah dibuat untuk membaca nilai device yang berubah karena user melakukan penekanan tombol atau memasukkan nilai set point melalui panel HMI. Contoh potongan ladder diagram pada rutin pembaca nilai device ditunjukkan oleh Gambar 5.

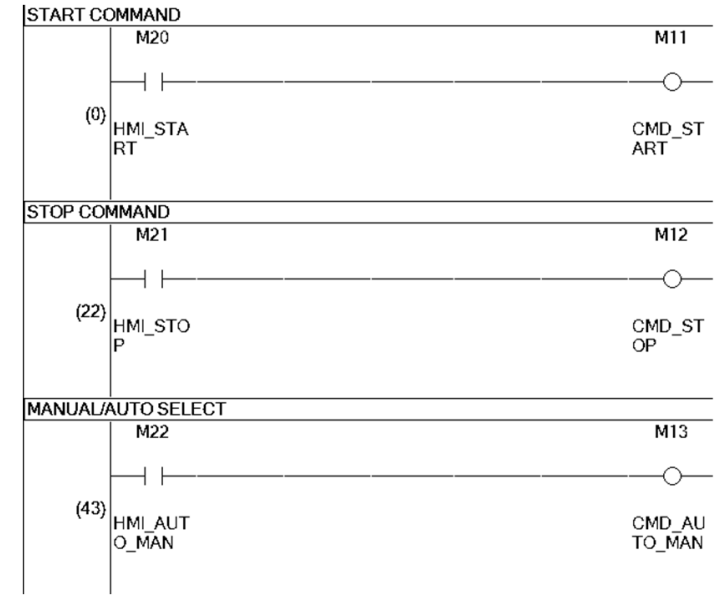

Gambar 5. Rutin program pembaca nilai device

\subsection{Hasil Pengujian}

Setelah program PLC dan layout HMI telah diinstall pada masing-masing piranti maka selanjutnya dilakukan pengujian simulator. Pada saat pengujian, PLC dan panel monitor HMI harus dikonfigurasi dengan protokol komunikasi yang sesuai. PLC dan panel monitor HMI mendukung beberapa protokol komunikasi dan pada pengujian ini dipilih protokol komunikasi TCP/IP melalui ethernet [20]. Selain PLC dan panel monitor HMI, sebuah PC juga disiapkan untuk keperluan troubleshooting. Ketiga perangkat ini dihubungkan satu sama lain menggunkan switch sebagai center node seperti yang ditunjukkan oleh Gambar 6 .

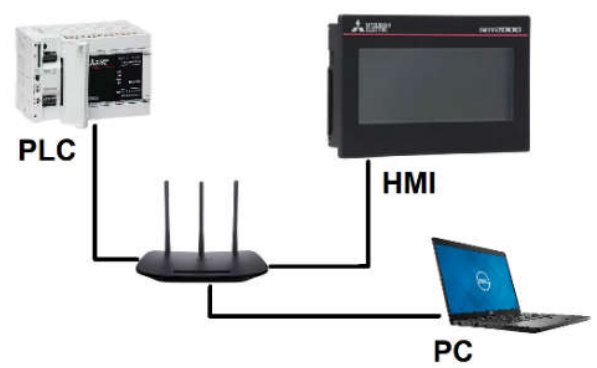

Gambar 6. Komunikasi antara PLC, panel HMI dan PC

Alamat IP untuk PLC, panel HMI dan PC diatur pada kelas yang sama. Pengalamatan IP kelas $\mathrm{C}$ dipilih untuk masing-masing perangkat ditunjukkan pada Tabel 2.

Tabel 2. Alamat IP perangkat

\begin{tabular}{|l|l|l|}
\hline No. & Perangkat & Alamat IP \\
\hline 1 & PLC & 192.168 .0 .111 \\
2 & Panel HMI & 192.168 .0 .118 \\
3 & Komputer/PC & 192.168 .0 .100 \\
4 & Switch (gateway) & 192.168 .0 .1 \\
\hline
\end{tabular}


Proses pengujian simulator simulator sortir bola ditunjukkan oleh Gambar 7 sedangkan hasil pengujian simulator ditunjukkan pada Tabel 3 .

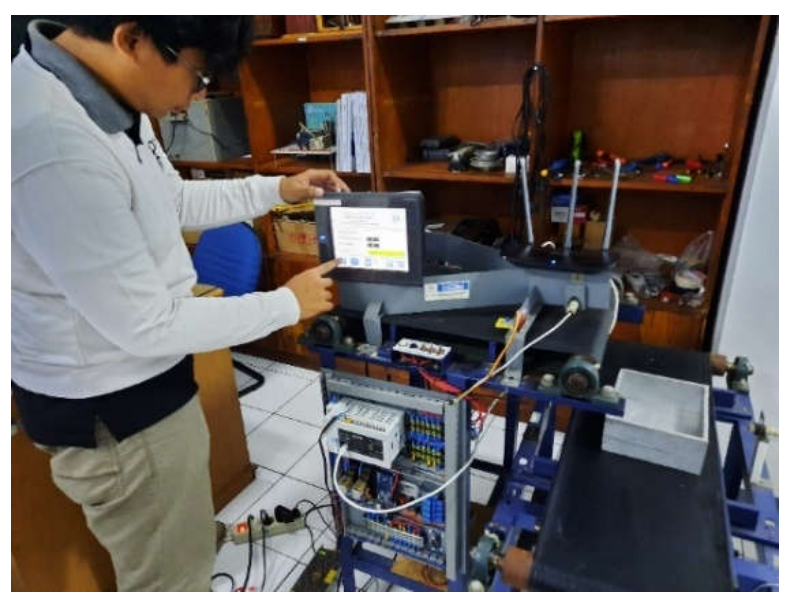

Gambar 7. Proses pengujian simulator sortir bola dengan sistem HMI baru

Terlihat dari tabel 3 hasil pengujian, simulator telah berhasil memenuhi semua poin pengujian sehingga dapat disimpulkan bahwa sistem HMI yang dikembangkan pada simulator sortir bola telah bekerja dengan baik. Dengan selesainya pengembangan ini maka simulator sortir bola dapat digunakan sebagai media pembelajaran bidang otomasi industri baik PLC maupun HMI.

Tabel 3. Hasil pengujian simulator

\begin{tabular}{|c|l|l|l|}
\hline No & Bagian HMI & Pengujian & Hasil \\
\hline $\mathbf{1}$ & Tombol START & $\begin{array}{l}\text { Jika ditekan, } \\
\text { simulator akan } \\
\text { beroperasi (mode } \\
\text { AUTO) }\end{array}$ & Ya \\
& & $\begin{array}{l}\text { Jika ditekan, } \\
\text { simulator akan } \\
\text { berhenti (mode }\end{array}$ & Ya \\
$\mathbf{2}$ & Tombol STOP & $\begin{array}{l}\text { AUTO) } \\
\text { Mode operasi yang } \\
\text { dipilih tersimpan di } \\
\text { PLC }\end{array}$ & Ya \\
& Tombol &
\end{tabular}

\begin{tabular}{|c|l|l|l|}
$\mathbf{4}$ & $\begin{array}{l}\text { Tombol RUN } \\
\text { KVY 1 }\end{array}$ & $\begin{array}{l}\text { Jika ditekan (ON), } \\
\text { konveyor 1 bergerak } \\
\text { (mode MANUAL) }\end{array}$ & Ya \\
$\mathbf{5}$ & $\begin{array}{l}\text { Tombol RUN } \\
\text { KVY 2 }\end{array}$ & $\begin{array}{l}\text { Jika ditekan (ON), } \\
\text { konveyor 2 bergerak } \\
\text { (mode MANUAL) } \\
\text { Nilai yang } \\
\text { dimasukkan }\end{array}$ & Ya \\
tersimpan di memori \\
$\mathbf{7}$ & Jumlah Bola (SP) & Ya \\
$\mathbf{8}$ & $\begin{array}{l}\text { Jumlah Bola } \\
\text { (Masuk) }\end{array}$ & $\begin{array}{l}\text { Angka yang tampil } \\
\text { sesuai jumlah bola } \\
\text { yang telah masuk } \\
\text { boks } \\
\text { Menunjukkan nomor } \\
\text { tahapan proses } \\
\text { Menunjukkan } \\
\text { informasi mengenai } \\
\text { tahapan proses yang } \\
\text { sedang berlangsung }\end{array}$ & Ya \\
\hline
\end{tabular}

\section{Kesimpulan dan Saran}

Panel monitor HMI telah ditambahkan pada simulator sortir bola dan berhasil memenuhi semua poin pengujian. Melalui penambahan sistem HMI ini, maka simulator sortir bola dapat dimanfaatkan oleh mahasiswa sebagai media pembelajaran teknologi otomasi industri khususnya PLC dan HMI. Dengan demikian, diharapkan tujuan capaian pembelajaran untuk menghasilkan profil lulusan yang berkompeten di bidang teknologi otomasi industri bisa diwujudkan.

Sistem HMI pada simulator masih dapat dikembangkan diantaranya adalah dengan menambahkan user level access, data logger dan alarm. User level access merupakan sistem keamanan yang diterapkan terkait dengan pemberian hak akses terhadap resource yang tersedia di HMI sesuai dengan level pengguna, misalnya: operator, leader dan administrator. Sedangkan adanya data logger dan alarm, bermanfaat untuk melakukan analisis dan troubleshooting terhadap permasalahan yang terjadi pada simulator.

\section{Ucapan Terima Kasih}

Ucapan terima kasih ditujukan kepada Lembaga Penelitian dan Pengabdian Masyarakat (LPPM) Universitas Dian Nuwantoro atas pendanaan melalui Penelitian Pengembangan Institusi dengan SK No 137/A.38.04/UDN-09/XI/2019.

\section{Daftar Pustaka}

[1] E. R. Alphonsus and M. O. Abdullah, "A review on the applications of programmable 
logic controllers (PLCs)," Renew. Sustain. Energy Rev., vol. 60, pp. 1185-1205, 2016, doi: 10.1016/j.rser.2016.01.025.

[2] M. Ito, "HMI Requirements Creation, as the Collaboration Work of Human and Machine in the Safety-Critical System," 2017, pp. 61-71, doi: 10.1007/978-3-319-64218-5 5.

[3] A. Ardanza, A. Moreno, Á. Segura, M. de la Cruz, and D. Aguinaga, "Sustainable and flexible industrial human machine interfaces to support adaptable applications in the Industry 4.0 paradigm," Int. J. Prod. Res., vol. 57, no. 12, pp. 4045-4059, 2019, doi: 10.1080/00207543.2019.1572932.

[4] P. Papcun, E. Kajati, and J. Koziorek, "Human machine interface in concept of industry 4.0," DISA 2018 - IEEE World Symp. Digit. Intell. Syst. Mach. Proc., pp. 289-296, 2018, doi: 10.1109/DISA.2018.8490603.

[5] A. Benesova, M. Hirman, F. Steiner, and J. Tupa, "Analysis of Education Requirements for Electronics Manufacturing within Concept Industry 4.0," Proc. Int. Spring Semin. Electron. Technol., vol. 2018-May, pp. 2-6, 2018, doi: 10.1109/ISSE.2018.8443681.

[6] A. Benešová and J. Tupa, "Requirements for Education and Qualification of People in Industry 4.0," Procedia Manuf., vol. 11, no. June, pp. 2195-2202, 2017, doi: 10.1016/j.promfg.2017.07.366.

[7] N. J. Harahap, "MAHASISWA DAN REVOLUSI INDUSTRI 4.0," ECOBISMA (Jurnal Ekon. Bisnis dan Manajemen), vol. 6, no. 1, pp. 70-78, 2019.

[8] D. Mourtzis, E. Vlachou, G. Dimitrakopoulos, and V. Zogopoulos, "Cyber- Physical Systems and Education 4.0 -The Teaching Factory 4.0 Concept," Procedia Manuf., vol. 23, no. 2017, pp. 129-134, 2018 , doi: 10.1016/j.promfg.2018.04.005.

[9] Htet Htet Aung | Thu Zar Thein, "Simulation and Implementation of PLC Based for Detecting Burned Potato Chips and Remove using PLCSIM and HMI," Int. J. Trend Sci. Res. Dev., vol. 3, no. 5, pp. 1644-1649, 2019, doi: https://doi.org/10.31142/ijtsrd26724.

[10] S. N. Edusainstek et al., "DESAIN DAN SIMULASI SISTEM HMI (Human Machine Interface) BERBASIS CITECT
SCADA PADA KONVEYOR PROSES DI INDUSTRI," Semin. Nas. Edusainstek, pp. 253-262, 2018.

[11] A. Septian MN, "Penerapan Trainer Human Machine Interface (HMI) Berbasis CXDesigner Sebagai Media Pembelajaran Programmable Logic Controller (PLC), " $J$. Inform. Univ. Pamulang, vol. 3, no. 4, p. 276, 2018, doi: 10.32493/informatika.v3i4.2391.

[12] A. G. Abdullah and A. P. Putra, "Water level measurement altitude trainer integrated with human machine interface," Indones. J. Sci. Technol., vol. 2, no. 2, pp. 197-210, 2017, doi: 10.17509/ijost.v2i2.8019.

[13] P. Khatri, K. K. Gupta, and R. K. Gupta, "Raspberry Pi based Smart Sensing Platform for Drinking Water Quality Monitoring System: A Python Framework Approach," Drink. Water Eng. Sci. Discuss., pp. 1-17, 2019, doi: 10.5194/dwes-2018-35.

[14] Omron, "Basics Of Programmable Controllers," 1999.

[15] B. Hollifield, D. Oliver, I. Nimmo, and E. Habibi, The high performance HMI handbook: A comprehensive guide to designing, implementing and maintaining effective HMIs for industrial plant operations. Houston: PAS, 2008.

[16] F. Ferri, A. D'Andrea, P. Grifoni, A. D’Ulizia, M. C. Caschera, and T. Guzzo, "The HMI digital ecosystem: Challenges and possible solutions," MEDES 2018 10th Int. Conf. Manag. Digit. Ecosyst., pp. 157-164, 2018, doi: 10.1145/3281375.3281397.

[17] A. Hossain and T. Zaman, "AC 2012-3605: HMI DESIGN: AN ANALYSIS OF A GOOD DISPLAY FOR SEAMLESS INTEGRATION BETWEEN USER UNDERSTANDING AND HMI Design: An Analysis of a Good Display for Seamless Integration Between User Understanding and Automatic Controls Abstract: In process a," Am. Soc. Eng. Educ., p. 14, 2012.

[18] P. Gruhn, "Human Machine Interface (HMI) design: The good, the bad, and the ugly (and what makes them so)," Proc. Annu. Symp. Instrum. Process Ind., pp. 110, 2011. 
[19] MITSUBISHI, MELSEC iQ-F FX5 Programming Manual (Instructions, Standard Functions/Function Blocks), M. MITSUBISHI ELECTRIC CORPORATION, 2014.

[20] Mitsubishi Electric Corporation, "Satellite Training Series 【PART 3】 Your First GOT." Mitsubishi Electric Corporation, 2016.

\section{Biodata Penulis}

Helmy Rahadian, menyelesaikan program sarjana di program studi Elektronika dan Instrumentasi Universitas Gadjah Mada tahun 2006 dan program magister Teknik Instrumentasi di Departemen Teknik Elektro dan Teknologi Informasi Universitas Gadjah Mada tahun 2011. Saat ini menjadi staf pengajar di program studi Teknik Elektro Universitas Dian Nuswantoro. Bidang penelitian yang ditekuni adalah instrumentasi industri, otomasi industri (PLC, HMI dan SCADA) serta industrial IoT system and networking.

M Ary Heryanto, menyelesaikan program sarjana di program studi Teknik Elektro Institut Teknologi Nasional Malang tahun 1997, kemudian menyelesaikan program magister Teknik Instrumentasi di Departemen Teknik Elektro dan Teknologi Informasi Universitas Gadjah Mada tahun 2008 dan program doktor ilmu elektro di Universitas Indonesia tahun 2017. Saat ini menjadi staf pengajar di program studi Teknik Elektro Universitas Dian Nuswantoro. Bidang penelitian yang ditekuni adalah kendali cerdas. 